\title{
THE HOLOCAUST AND GENDER: REMEDIATION AND COMPENSATION
}

\author{
Elizabeth R. Baer and Myrna Goldenberg, eds
}

Experience and Expression: Women, the Nazis, and the Holocaust

Detroit: Wayne State University Press, 2003, 321 pp., ISBN 0-8143-3062-2 (hbk), 0-8143-3063-0 (pbk)

A whispered warning in the cattle car that had just arrived in Auschwitz reached the ears of Cecilie's mother. "'Give the child to an older woman! . . . Tonight will be the gassing and burning of the very young, the old, and mothers with children!"' (Klein, 1988: 77). Taking the grandchild from her daughter's arms, the quick-thinking Mrs Goldenzeil lied. Women with children, she said, would be spared hard labour. In the hasty parting that followed, she also urged her elder daughter: "Promise to look after Cillie"' (Klein, 1988: 77), thereby renewing a maternal commitment that saved both sisters' lives. They became known as 'die zwei gute Geschwister' - the two good sisters.

What appears here of motherhood's particular vulnerability and increased hope of survival in bonding - either of real or 'camp' sisters - represents only the most obvious themes of special relevance to women brought forward when the Holocaust is viewed through the lens of gender. Other treatment to which both sexes were subjected but differently experienced includes having all body hair shaved on arrival, the women naked under the indifferent eyes of male prison barbers and the often lewd gaze of Nazi guards. Females, unlike males, had to fear menstrual blood - and its cessation. Having been socialized to value maternity, inmates feared permanent sterility as a result of amenorrhoea, a common result of starvation. In sum, it seems to be simple common sense to conclude that, although Jews were targeted for death - not as women or men but as Jews - the same hell differed in both experience and expression.

I have spelled out above what you might automatically assume because you, who hold the European Journal of Women's Studies in your hands, aren't really frontrow readers for Experience and Expression: Women, the Nazis, and the Holocaust. Instead, Baer, Goldenberg and their stellar contributors have invested significant energy in convincing an implied audience of male Holocaust scholars that disaggregating historical aspects of the Shoah by gender is not high treason, distortion, or outrageous kowtowing to a feminist mafia for whom the genocide is 'simply' another example of patriarchy run amok. That such argumentation remains necessary says something sad about the present state of Holocaust scholarship two decades after 1983 when the first conference devoted to women was held.

This book, then, remains, like many of the studies before it, compensatory and remedial, which is not to say it lacks value. Baer, Goldenberg and contributors appear unaware of Féminismes et Nazisme edited by Liliane Kandel in 1997, which already innovates feminist Holocaust scholarship in ways that the later work claims it has pioneered. Both are characterized by interdisciplinary, self-scrutinizing, highly differentiated viewpoints. Both insist on the importance of particularity, case studies that necessarily differ from one another just like humans do. And as the title of Kandel's text suggests, feminisms, in the plural, bring controversy with them.

One obvious danger of feminist interrogation lies in the seduction of 'essentializing gender difference', against which Pascale Rachel Bos warns, for instance, in Chapter 2, 'Women and the Holocaust: Analyzing Gender Difference'. Reviewing the literature, she questions viewpoints that, on the basis of subjective testimony and the avatars of memory, claim superiority for one gender over the other: 'concluding that women were socialized to cope with hunger "better" because 
they hoarded and saved food, as is sometimes suggested, is deceptive and also incorrect' (p. 34). Could 'slower metabolism' have played a role? Although Myrna Goldenberg's 'Food Talk: Gendered Responses to Hunger in the Concentration Camps' contradicts Bos's viewpoint - Goldenberg juxtaposes male and female narratives concerning food and finds dissimilarity - difficulty in identifying 'facts' remains, and this is no surprise in light of the general challenge to historiography during these hideous times. Yes, the Nazis kept meticulous records but also did their best to suppress information and destroy evidence.

Reliance on memoir suggests the benefit of enlisting 'feminist theories of autobiography' to consider whether 'female authors are influenced by different literary and cultural models' (p. 35) than men so that they fashion 'facts' or highlight events in gender-specific ways. For Bos, men's socialization to autonomy informs an emphasis on individual survival, in contrast to the sisterhoods, suggested earlier, that women celebrate. Similarly, my own systematic reading of French memoirs by men and women revealed an unmistakable gender distinction in the insistence by men on a patriotic discourse linked to military service in the Great War and resulting in a heightened sense of betrayal at their exclusion from the body politic. Needless to say, French women's experience of anti-Semitism differed.

Now, if contributors to Baer and Goldenberg limited themselves to arguing for recognition by Holocaust scholars of these rather obvious distinctions, the book's appeal would be greatly diminished. Fortunately, this is not the case. Like Kandel's anthology, though more systematically arranged, Baer and Goldenberg extend the reach of women's studies of the Holocaust to focus not only on Jewish women as both victims and agents in resistance, but also on gentiles: a French Protestant resistance agent, Madeleine Barot, for instance, who saved many lives, often in cooperation with the young Jewish 'Colibri', is profiled by Judith Greenberg; Sinti and Roma women are discussed by Sybil Milton; and 'Involuntary Abortions of Polish Laborers' is sketched by the intrepid Anna Rosmus, famous in Germany for sleuthing her home town's disreputable past and acting as its persona non grata of conscience. Two articles on nurses in 'euthanasia' programmes that murdered tens of thousands of mentally and physically disabled 'Aryans', including children, also ask important questions about collaboration. (Though a couple of inadvertently comic moments occur in Susan Benedict's consideration of 'Caring while Killing'. Might the nurses have said 'no'? 'There has been no proof of a single case of retaliatory action against someone who refused to participate in killing operations, except for transfer to the eastern front' [p. 105] - which many felt equalled a death sentence. We also learn that 'the killing required some degree of force and unpleasantness for the patient' [p. 99].)

Needless to say, there should be little humour in the topic and, in fact, the secondary literature provided here is often as painful a read as the primary sources. In 'Ruptured Lives and Shattered Beliefs: A Feminist Analysis of Tikkun Atzmi in Holocaust Literature', Susan Nowak looks at how women tried to repair (tikkun) the self (atzmi) under conditions designed to annihilate any sense of personhood. For instance, 'each morning townspeople watch the prisoners' procession, spitting at them, eyes glowing with hatred', which leads Rena, the narrator, to conclude, "We are not human beings to them ... we are lower than dogs"' (p. 189). Filthy, lice-infested, autobiographers Rena Kornreich Gelissen and Elisabeth Gille, under Nowak's gaze, have made their 'individual lives ... the basis upon which ... to mend the self-contempt destroying their ... self-respect' (p. 182). Remembering and announcing the horror become central pillars in a renewed architecture of mind. 
But memory cheats, and other, venal forces distort commemoration. The book's concluding chapters confront this potentially overwhelming problem. In 'Anne Frank: The Cultivation of the Inspirational Victim', Catherine A. Bernard regrets the counterfeit, even shameful, use to which Anne Frank's diary has been put, especially when the famous saccharine lines concerning the goodness of humanity sugarcoat the horror that will prematurely end the young author's life. And in three final essays on media and works of art, including fiction, the relationship between imagination and reality is thematized. What Adorno might have meant by 'no poetry after Auschwitz' is the incommensurability of metaphor to the incontrovertible, final fact of death. Still, some claim can be made for artists performing a service that history cannot. Stephen C. Feinstein finds that 'Feminist Artistic Installations about the Holocaust' confront historicity by frankly revealing their constructed artificiality. Making no claims to authenticity, they act, instead, as 'guardians of memory' (p. 256), an act into which viewers are welcomed. Likewise, S. Lillian Kremer holds that 'witnessing by the imagination' based on research, in novels by talented, empathic Jewish women who, although they were not there, 'underscore the gendered dimensions of women's suffering and of their coping strategies' (p. 261) is legitimate and helpful, without recourse to 'essentialist positions' that deny the complexity of history as it stormed over men as well.

The concluding chapter, Rebecca Scherr's 'The Uses of Memory and Abuses of Fiction: Sexuality in Holocaust Film, Fiction, and Memoir', weighs in with a sobering counterpart to Kremer's approbation. The former, having chosen uncontested works of art, finds that fiction has its legitimate place in Holocaust scholarship. Scherr, basing her analysis on suspect subjects, disagrees: 'the narrative works of the survivor memoirists own a kind of authenticity that Holocaust fiction writers can never match' (p. 294). True at least for Liliana Cavani's film The Night Porter and D.M. Thomas's novel The White Hotel. Scherr finds that sexuality and eroticism are introduced for commercial reasons; the Holocaust background contributes a heightened sadistic appeal and is not present for its own sake, to enable rereading with an ethical purpose in mind. Efforts to understand the Shoah are undermined, not furthered, by these particular fictions.

Unless we conclude with Margarete Mitscherlich for whom 'L'antisémitisme est une maladie male' (quoted in Kandel, Préface d'Élisabeth de Fontenay, 1997: 5). I confess, my own feeling is that, comparing anti-Semitism to American racism (my field of expertise), sexual sadism and male rivalry do indeed play a role in lynchings and murder. But this possibility is not entertained in Experience and Expression, which I recommend nonetheless.

\section{REFERENCES}

Kandel, Liliane, ed. (1997) Féminismes et Nazisme. Paris: Publications de l'Université de Paris. (Reprinted by Odile Jacob, 2004.)

Klein, Cecilie (1988) Sentenced to Live. New York: Holocaust Library.

Tobe Levin

University of Frankfurt and University of Maryland 